\title{
International Organizations and Global Labor Standards
}

Friederike Römer, Jakob Henninger, and Thuy Dung Le

\section{INTRODUCTION}

Working conditions and labor standards vary drastically across countries and sectors. Especially - but not only - in the Global South, workers often face hazardous conditions at their workplace resulting in occupational accidents

This chapter is a product of the research conducted at the Collaborative Research Center "Global Dynamics of Social Policy" at the University of Bremen. The center is funded by the Deutsche Forschungsgemeinschaft (DFG, German Research Foundation)—project number 374666841—SFB 1342.

F. Römer $(\varangle) \bullet J$ J. Henninger

Institute for Intercultural and International Studies (InIIS) and

Collaborative Research Centre 1342 "Global Dynamics of Social Policy”,

University of Bremen, Bremen, Germany

e-mail: froemer@uni-bremen.de; jakob.henninger@uni-bremen.de

T. D. Le

Bremen International Graduate School of Social Sciences (BIGSSS), University of Bremen, Bremen, Germany

e-mail: dle@bigsss-bremen.de

(C) The Author(s) 2021

K. Martens et al. (eds.), International Organizations in Global

Social Governance, Global Dynamics of Social Policy, https://doi.org/10.1007/978-3-030-65439-9_3 
and work-related diseases. Examples of perilous circumstances and deathly events are tragically abundant. Based on data collected by the International Labour Organization (ILO), Hämäläinen, Takala and Boon Kiat $(2017,4)$ estimate that there are 2.78 million deaths due to work-related causes each year. ${ }^{1}$ This figure shows that the issue goes beyond widely publicized incidents such as the collapse of the Rana Plaza factory in 2013 which caused the death of at least 1134 workers. Improving working conditions for people across the world is therefore an urgent and topical matter. But it is not limited to standards on occupational safety: In fact, achieving consensus on what should constitute a set of global (minimum) labor standards is crucial to prevent a potential 'race to the bottom' that places competitiveness and maximum profits over safe and humane working conditions.

In this chapter, we set out to investigate how international and regional organizations have positioned themselves toward global labor standards. Two questions guide our analyses. First, we want to outline why there is no agreement among International Organizations (IOs) on what constitutes a set of desirable global labor standards. We argue that disagreement both between and within IOs persists for two reasons, namely conflicting ideological beliefs on the desirability of labor standards, but also because of strong regional differences. In effect, this has contributed to a decentralized system of global governance which employs a variety of differentially effective enforcement mechanisms (see Hurd 2003). Second, we will take a look at how labor standards are governed at the level of regional organizations, investigating whether regional organizations might in fact be better equipped to come to agreements given that they represent more homogeneous groups of countries than IOs.

The chapter starts by briefly exploring various conceptualizations of labor standards and by outlining the two contesting discourses, namely the 'social' and the 'neoliberal' discourses, and how labor standards, notably Freedom of Association and Collective Bargaining (FACB) rights, are perceived in each of these modes of thought. It proceeds to present the positions of three key international actors, the ILO, the World Trade Organization (WTO) and the World Bank (WB). This selection does not constitute an exhaustive mapping of the field, where other organizations, notably the United Nations Human Rights Council and the Organisation for Economic Co-operation and Development (OECD), are also influential actors.

${ }^{1}$ Their estimates are based on data for the years 2014 and 2015 (Hämäläinen et al. $2017,5)$. 
Restricting our analysis to the ILO, the WTO and the WB, however, allows us to juxtapose an organization strongly in favor of labor standards, an organization that claims to not be responsible for or even in opposition to labor standards, and an organization that has shifted its position to some extent.

Beyond the IOs, in this chapter we will assess how two regional organizations, the Association of Southeast Asian Nations (ASEAN) and the Southern Common Market (Mercosur), have approached the topic of labor standards. ASEAN and Mercosur are neither the only nor the most influential standard setters in the population of regional organizations - for example the European Union (EU) is much more active in defining standards and enforcement mechanisms (see e.g. Orbie and Babarinde 2008). ASEAN and Mercosur are, however, interesting cases to illustrate how social and neoliberal discourses shape regional approaches to labor standards in contexts where labor-intensive industries are widespread among member states and introducing farreaching sets of labor standards might hamper competitiveness.

\section{Mapping the Population and Discourses of IOs Active in the Field of Global Labor Standards}

There is no agreement on what the term 'labor standards' denotes. As work may take on a variety of forms and is happening in highly diverse contexts, defining and delimiting standards is highly contextual. When assessing organizations' positions, however, it is helpful to rely on a definition that can be used as a benchmark. Based on a systematic literature review, ${ }^{2}$ we find that authors agree that labor standards are a multidimensional concept that is made up of a number of different sub-components, but that there is no general consensus on the sub-concepts that should be included in a definition. Over 20 different components are mentioned at least once, among them are "hiring regulations" (Gwartney et al. 2012; Murillo 2005; Potrafke 2013; Blanchard and Wolfers 2000; Nickell 1997; Botero et al. 2004), laws that prohibit forced labor (Anner 2012; Anner and Caraway 2010; Barrientos and Smith 2007; Cingranelli and Richards 2014; OECD 2000; Portes 1994) and a right to unemployment benefits (Blanchard and Wolfers 2000; Botero et al. 2004).

What explains the gaping differences between definitions? To some extent, the breadth (or narrowness) of definitions aligns with two

\footnotetext{
${ }^{2}$ We conducted a search on Web of Science using the search terms "labo* rights" and "labo* standards". We restricted the review to the most influential articles, which we defined as those having $>100$ citations and being in relevant categories. This amounted to 15 studies.
} 
competing views on the desirability and reach of such standards: the "neoliberal' and the 'social' perspectives. According to the neoliberal perspective, labor standards are problematic because they undermine the 'free' operation of the market, hampering the generation of profit. In this view, labor standards are only beneficial when they are geared toward productivity and compliance, not decommodification. Labor standards are thus seen critically, and a limited set of rights-if any-is favored. The social discourse on the other hand includes a strong commitment to a set of farreaching rights and standards, even though there is often considerable disagreement in regard to insider/outsider divides within the social discourse (see also Ehmke et al. 2009, 17-20 for a detailed discussion of the positions of capital and labor).

Interestingly, authors included in the literature review agree in regard to one subcomponent of labor standards. All definitions include FACB rights. As FACB rights allow workers to organize and represent their own interests, they are a basis for many other rights and standards (see e.g. Langille 2005, 430; Berliner et al. 2015). "The formation of a union, good faith collective bargaining, and withholding one's labor to improve terms and conditions of employment are enabling rights. They do not dictate outcomes but guarantee procedures that mitigate the inherent power imbalance in the employment relationship" (Anner 2012, 610). The right to freedom of association and collective bargaining thus affects in how far markets are regulated and the way society is organized as a whole (Mosley 2010, 103-104). Because FACB rights touch upon fundamental class and power relations, they are likely to be contested and are in fact threatened in many countries (Visser 2019). In this chapter we will therefore use FACB rights as a benchmark to assess how IOs have approached Global Labor Standards.

We examine the stances of three major IOs toward labor standards: Firstly, the ILO, which remains the most influential standard-setting international organization in the field of labor standards. Other organizations continue to rely on the cognitive authority of the ILO to define benchmarks in the field (Ehmke et al. 2009, 14; see also Baccaro 2014; SenghaasKnobloch 2019). However, as was foreshadowed in the introduction, we also consider organizations that are not 'responsible' for labor standards in the narrower sense: On the one hand, we include the WTO, which could potentially provide effective enforcement instruments but has refrained from taking an active position on labor standards. On the other hand, we 
discuss the position of the World Bank which has moved from contestation to cooperation with the ILO.

It is important to note that a large literature attests that IOs are not the only influential actors in the field of global labor standards (Hendrickx et al. 2016; Hassel 2008; Hassel et al. 2008; Alston 2004). Multistakeholder initiatives, multinational corporations, international unions, NGOs and grassroots movements have become important actors, particularly when it comes to implementation, control and enforcement (see e.g. O'Rourke 2003; Kolben 2011; Anner 2012). Of special relevance in this context is the UN Global Compact, which is something of a hybrid. Though initiated and overseen by the United Nations (UN), it is a voluntary association of businesses that aims to ensure adherence to a set of social and environmental standards (see Ruggie 2002; Hurd 2003). ${ }^{3}$ Giving an account of all these different organizations and initiatives would be outside the scope of this chapter. However, we will touch upon them in those cases where they systematically influenced or were influenced by IOs.

\section{The International Labour Organization: The Promoter of Labor Standards as a Social Project}

In 2019, the ILO celebrated its centenary anniversary. It is the oldest and the only global body responsible for the formulation and inspection of internationally recognized labor standards. The ILO is also the only tripartite UN agency, having succeeded in involving representatives of governments, employers and workers in its decision-making process (ILO 2002). To date, the ILO has established 190 Conventions (including eight Fundamental Conventions, four Governance Conventions and other Technical Conventions), 6 Protocols and 206 Recommendations. FACB rights are fundamental to the ILO, which is first and foremost mirrored in its institutional set-up - union members supply the worker representatives for its tripartite structure (ILO 2019b). Furthermore, promoting FACB rights has been one of the ILO's aims from the start. The Declaration of Philadelphia mentions both "freedom of expression and of association" and "the effective recognition of the right of collective bargaining" (ILO 1944, 4-5). The two relevant conventions, C087 - Freedom of Association

\footnotetext{
${ }^{3}$ For a critical assessment of the "promise-performance gap" of the UN Global Compact, see Sethi and Schepers (2014).
} 
and Protection of the Right to Organise Convention (No. 87) and C098 Right to Organise and Collective Bargaining Convention (No. 98), date from 1948 and 1949 respectively. Importantly, however, the social discourse pursued by the ILO has gone far beyond focusing on the enabling FACB rights. ILO conventions and regulations define labor standards in regard to a wide array of different aspects, covering not only protection for those at work, but also protection for those unable to work (unemployment, old age, sickness and disability insurance). This far-reaching definition of labor standards reflected by a large number of conventions has also been called the "maximalist approach" (Alston 2004, 465).

It has been argued that the social discourse pursued by the ILO was relatively strong in a world system characterized by two competing political ideologies. The collapse of the Soviet Union removed the threat of communism as a credible alternative to market capitalism and consequently weakened the ILO (Kaufman 2004, 552). During the 1990s, the organization shifted from a maximalist approach to promoting a narrower set of standards. In 1998, the 'Core Labour Standards' (CLS) were introduced. They are comprised of eight fundamental rights conventions which cover four dominant issues: freedom from forced labor, freedom from child labor, freedom from discrimination at work and the freedom to form and join a union and to bargain collectively. ${ }^{4}$ Importantly, the CLS apply to all ILO member states regardless of whether they have ratified them (ILO 1998). This constituted an important shift in the social discourse. CLS were framed as truly global, a set of rights which does not need national government approval.

The literature agrees on the fact that the introduction of the CLS in 1998 marks a watershed (Alston 2004; Alston 2005; Langille 2005; Maupain 2005; Standing 2008). However, there is sharp disagreement about whether they represent an upgrading or downgrading of labor standards in the international regime. Numerous authors have argued that the CLS reflect a defeat of labor interests because they focus on a smaller

\footnotetext{
${ }^{4}$ Freedom of association and collective bargaining: C087 - Freedom of Association and Protection of the Right to Organise Convention, 1948 (No. 87), C098 - Right to Organise and Collective Bargaining Convention, 1949 (No. 98); Forced labor: C029 - Forced Labour Convention, 1930 (No. 29), C105 - Abolition of Forced Labour Convention, 1957 (No. 105); Discrimination: C100 - Equal Remuneration Convention, 1951 (No. 100), C111 Discrimination (Employment and Occupation) Convention, 1958 (No. 111); Child labor: C138 - Minimum Age Convention, 1973 (No. 138), C182 - Worst Forms of Child Labour Convention, 1999 (No. 182).
} 
group of rights at the expense of the much broader body of labor standards covered by the conventions, thus marking a very significant departure from the approach that all human rights are equally important (see e.g. Alston 2004, 2005). There are, however, also a number of voices arguing that the CLS were an adequate response to the increasing dominance of trade liberalization and neoliberalism in national and international institutions. Maupain stresses that since the introduction of the CLS, ratification of the respective conventions has increased considerably (Maupain 2005, 439). Despite criticism of the loose wording in the Conventions and Recommendations, the CLS nevertheless stand as the most influential source of defining minimum standards, with the right to freedom of association and collective bargaining remaining at the heart of the ILO's goals (Standing 2008; Langille 2005).

Furthermore, the CLS do not stand alone but are accompanied by the Decent Work Agenda (DWA), which includes a more encompassing conceptualization of labor standards. The DWA encompasses the CLS as one of four pillars next to employment creation, expansion of social protection and promotion of tripartite agreements as well as social dialogue (Bakvis and McCoy 2008, 2). Through the CLS and the DWA, the ILO thus continues to define benchmarks for global labor standards that include and go beyond FACB rights.

In recent years, however, the ILO's significance has been challenged in two ways. First, the ILO has had to consider its relations to other actors that have newly emerged or gained importance. The role of international unions has continued to expand in scope in recent years, with unions developing into effective actors in international labor relations (Fairbrother and Hammer 2005; Croucher and Cotton 2009; Ford and Gillan 2015). Unions directly negotiate with multinational companies and sign International Framework Agreements that ensure the company-wide respect of labor standards across multiple countries (Dehnen 2013; McCallum 2013). Similarly, grassroots and civil society organizations are channeling consumers' awareness of working conditions in the global production chain. This has resulted in influential public campaigns that have led to responses from multinational corporations (Barrientos and Smith $2007,715)$. Among those responses are increases in the use of corporate codes of conduct since the 1990s (Bartley 2005). The ILO's role has been one of support through capacity building, technical assistance and provision of legitimacy (Baccaro 2014, 265), but actual control over these corporatist actors is limited. This has led some authors to the conclusion that 
the ILO has not been able to defend workers' interests and that the social discourse has failed (see e.g. Farnsworth 2005; Hilgert 2009). In a more recent study, however, Thomas and Turnbull (2017) find that policy entrepreneurs within the ILO are successfully promoting the idea that a new form of governance is needed that can target transnational actors, notably multinational corporations.

A second challenge arises from the fact that the ILO has traditionally tended to represent formal workers and to neglect the situation of marginalized workers such as informal workers or migrant workers (Cox 1980; Prügl 1999; Vosko 2002; Whitworth 1997). Yet these make up a large part of the global workforce. The ILO's legitimacy as the organization most knowledgeable about any issue related to labor thus hinges on incorporating and supporting these groups that have not traditionally been its main clientele. Furthermore, interest groups representing informal workers are emerging across the globe. The response of the ILO has been to suggest unionizing the informal workforce. The report "Organizing Informal Workers into Trade Unions" is a guide that is supposed to help unions identify and organize relevant populations (ILO 2019a). One could conclude that Vosko's (2002) claim that the ILO seems to be less market-oriented than in previous years still holds today, and that a labororiented discourse on labor standards prevails, with FACB rights as the fundamental principle. The ILO thus appears to continue to normatively define labor standards within the global discourse in a comparatively encompassing way.

\section{The World Trade Organization: The Persistent Trade Promoter}

The WTO is the largest international economic organization in the world. In contrast to the ILO's tripartite structure, the WTO gathers only governmental and business representatives at the negotiating table of trade treaties and is operated by consensus. The bargaining power of workers or domestic politics in labor standards promotion is often limited throughout the process. The WTO has persistently pursued a neoliberal discourse, which challenges labor-related laws and regulations as factors of market distortion. According to this point of view, there is no obligation for the WTO to contribute to ensuring adherence to these standards.

From the 1980s onward, the debate on 'social clauses' raised the question as to whether there should be a formal link established between global trade and global labor standards. Interestingly, it was not primarily the 
ILO that initiated this discussion. In fact, among ILO officials there was some reluctance to adopt strong sanctioning mechanisms in order to achieve compliance to labor standards (Haworth et al. 2005, 1946) and international unions, notably the International Confederation of Free Trade Unions/International Trade Union Confederation (ICFTU/ ITUC), took the initiative instead (van Roozendaal 2002). The main argument of the international unions was that there was a risk of a 'race to the bottom' in the global trade and production network. The argument claims that in a globalized economy, weak labor standards are a competitive advantage (Chan 2003; Davies and Vadlamannati 2013; Drezner 2001 ). Low labor standards in one country may therefore trigger a deterioration in labor standards in other countries which face competitive pressures to weaken or refrain from strengthening their own labor standards. A social clause would have allowed importing countries to make use of trade sanctions against exporting countries that did not respect a previously defined set of labor standards (Van Liemt 1989).

The proposition to include a social clause was met with fierce opposition by developing countries in the Global South who believed this clause would be used for protectionist purposes. Workers' representatives were also divided on the issue: Those from countries with stronger labor standards supported the clause, whereas workers from countries with lower standards faced a dilemma, as raising labor standards posed a threat to competitiveness and the creation of new jobs (Stallings 2010, 128). The last major effort to link labor standards into global trade through concerted efforts of the ILO and the WTO took place at the World Trade Organization Ministerial Meeting in Singapore in 1996. At the conference, all WTO member governments agreed to committing to core labor standards, but emphasized that the WTO should not be the body responsible for enforcing them. Instead, the WTO pointed to the ILO as the competent body responsible for setting and monitoring labor standards.

The WTO talks held in Seattle in 1999 ultimately resulted in a failure to make any progress on the contents of the next round of global trade negotiations. One of the main causes of dissent among the participants was again the issue of including labor standards in international trade agreements (Bhagwati 2001). Given the shortcomings of multilateral trade negotiations, the number of bilateral trade agreements outside the ambit of the WTO has since exploded. A number of these include social clauses. In the global discourse, however, the WTO ultimately retained the position that labor standards are neither its competency nor 
responsibility. Even though the secretariats of the ILO and WTO work together on technical issues under the banner of 'coherence' in global economic policy making, there is evidence that labor standards are not only not promoted by the WTO, but that they are framed as impeding WTO objectives. Analyzing World Trade Reports from 2003-2017, Delgado (2019) finds that the WTO Secretariat continues to frame deregulatory reforms as desirable.

\section{The World Bank: The Advocate for Neoliberalism in Labor Standards as a Development Project}

The International Financial Institutions (IFIs), that is the World Bank, the International Monetary Fund (IMF) and the regional development banks, have often put labor standards into question and, for the sake of a development project, demand more labor flexibility over labor protection (see e.g. Abouharb and Cingranelli 2007; Anner and Caraway 2010). Empirical studies have shown that IFIs have actually undermined labor rights in the countries in which they were active. For instance, Blanton, Blanton and Peksen (2015) find that policy reforms recommended by IFIs undermined collective labor organization and the adoption of protective laws (see also Martin and Brady 2007).

The World Bank is an informative example of how ideas and discourse may evolve within IOs (Béland and Orenstein 2013). Having followed a neoliberal agenda from the 1980s, demanding structural adjustments in return for much of its lending, the World Bank refused to promote labor standards for a long time (Murphy 2014). From the late 1990s onward, however, the institution entered into dialogue with the ILO and with unions as well as civil society organizations (Hagen 2003; Murphy 2014). It is important to note, however, that $\mathrm{FACB}$ rights were only promoted once it had been proven that they would not threaten the main objective of the neoliberal discourse, that is economic growth. In response to a study that failed to find negative impacts of freedom of association and collective bargaining rights on economic growth, its executive board agreed on a statement in support of "the promotion of good practice related to all four Core Labour Standards" (Fryer 2003, 8).

The World Bank also changed the methodology of its influential Doing Business report to no longer penalize countries with strong labor regulations in its "ease of doing business" index (Murphy 2014, 414). Labor standards also figure in the World Bank's Environmental and Social 
Framework, in the second set of standards. The Environmental and Social Standards (ESS) 2 "Labor and Working Conditions" has the following objectives with regard to World Bank projects: health and safety at work, fair treatment, non-discrimination and equal opportunity, protection of vulnerable workers including migrants, prevention of forced and child labor, the support of "principles of freedom of association and collective bargaining of project workers in a manner consistent with national law" and the creation of complaints mechanisms (World Bank 2018, 1). The guidelines reference the eight ILO Conventions that constitute the CLS (World Bank 2018, 1-2). Thus, the World Bank has moved from a position of contestation of ideas brought forward by the ILO to a more cooperative stance.

\section{Regional Organizations in the Regime of Global LABOR GOVERNANCE}

In this section we examine regional organizations' stances toward labor standards and specifically FACB rights. As outlined in the introduction, labor standards are highly contextual, and the sets of standards and rights which are considered both desirable and feasible are likely to differ between countries and regions. As we have shown, regional differences have in some instances led to deadlock at the international level, notably within the WTO. Regional organizations as intermediary levels of agency between the nation-state and global institutions (Börzel and Risse 2009) may be better equipped to avoid such deadlocks. The groups of countries coming together in regional organizations tend to be more similar to each other than those involved in global multilateral negotiations, and therefore decision-making processes are less protracted (Yeates and Deacon 2009, 470).

Both ASEAN and Mercosur have member states that were opposed to the social clause within the WTO. The two organizations differ, however, in regard to how much their member states rely on labor intensive production, and the share of exports as a percentage of GDP is higher among ASEAN member states, making them more dependent on cheap labor (Fink and Rempe 2017). Another difference stems from the fact that while FACB rights remain limited in most ASEAN member states, Mercosur's approach to FACB rights is shaped by the strong involvement of trade unions at the national level. This is mirrored in the ratification of the 
relevant ILO treaties. Whereas only four and six of the ten ASEAN member states have ratified ILO conventions No. 87 and No. 98 on FACB rights respectively, all Mercosur member states have done so. ASEAN has in recent years started promoting FACB rights, but this has been piecemeal and with limited impact on member states. Mercosur's approach to FACB rights on the other hand is more participatory, as evidenced both by the strong involvement of trade unions in the elaboration of labor rights declarations, but also in the emphasis put on these rights in the declarations themselves.

\section{The Association of Southeast Asian Nations (ASEAN)}

ASEAN member states have a mixed track record when it comes to engagement with global labor governance. ${ }^{5}$ Before the early 2000s, ASEAN did not explicitly include human rights in its agenda (Davies 2013, 385-386) and did not adopt a social approach to labor standards either. Questions of labor standards were peripheral (O'Brien 2008, 146), even though sectoral issues like work environment (ASEAN 2012b), the reduction of child labor (ASEAN 1993), and occupational health and safety (ASEAN-OSHNET 2015) were discussed. ASEAN was even hostile toward the promotion of labor rights in international forums. In fact, the organization's Economic Ministers' Meeting in April 1996 announced their refusal to accept social clauses in the WTO (Mah 1998, 297).

From the early 2000s, ASEAN adopted a discourse more amenable to workers' rights and the concept of "people-centered ASEAN" became a leitmotif in many of the organization's documents (Morada 2008). This shift resulted, among other things, in the 2012 ASEAN Human Rights Declaration (AHRD). While it should be stressed that it is non-binding, the Declaration includes many workers' rights, including the right to social security and freedom from forced labor (ASEAN 2013, 5-8). In regard to FACB rights, however, the declaration contains the limitation that these rights must be "in accordance with national laws and regulations" (ASEAN 2013, 8). In 2012, ASEAN also issued an "ASEAN Guideline on Good Industrial Relations Practices" calling for "[f]reedom of association and the effective recognition of the right to collective bargaining" (ASEAN 2012a, 3). Furthermore, there is some evidence that

\footnotetext{
${ }^{5}$ Out of the ten ASEAN member states, only Cambodia, Indonesia and the Philippines have ratified all Core ILO Conventions (Brown 2016, 35-36).
} 
ASEAN is responding to the ILO's cognitive authority with regard to its "Decent Work" discourse, the concept appearing in documents such as the "ASEAN Socio-Cultural Community Blueprint 2025" (ASEAN 2016a) and the "Vientiane Declaration on Transition from Informal Employment to Formal Employment towards Decent Work Promotion in ASEAN" (ASEAN 2016b). The objectives set out for labor standards in the Blueprint are detailed in ASEAN Labor Ministers' Work Programs and the Work Plans of subsidiary bodies (ASEAN 2017) with at least the implicit goal of harmonizing labor laws, including industrial relations (Sale 2020,38 ).

Regional free trade agreements also tend to not include labor provisions: For instance, the proposed Regional Comprehensive Economic Partnership between ASEAN countries, China, Japan, South Korea, Australia and New Zealand, is unlikely to do so (Brown 2016, 47). Truly regional frameworks on labor standards are also rare: An exception is the ASEAN Convention against Trafficking in Persons signed in 2015, which builds on global initiatives and requires ASEAN member states to transpose it into their national legislations. ASEAN has thus taken up global discourses seeking to harmonize labor standards across member states, but these attempts have been met with little success (Brown 2016; Sale 2020).

Both the concept of "organizational field" and the intrinsic features (Niemann et al. in this volume) of ASEAN may explain some of these difficulties. Firstly, with regard to the former, Sale (2020) argues that differing belief systems underlying national labor laws mar harmonization. For instance, labor market regulation in Malaysia focuses on employers' interests in providing an inexpensive workforce, whereas worker protections take center stage to a larger extent in the Philippines, indicating that harmonization of their labor standards will be difficult (Sale 2020). But lack of progress in regional harmonization of labor standards can also be traced back to intrinsic features of the organization: ASEAN has in fact long prided itself on its soft approach as well as prevailing norms of noninterference and consensus decision-making, so much so as to call this the "ASEAN way" to approach regionalism (Acharya 1997, 320). Consequently, many of the above-mentioned regulations, such as the AHRD, remain non-binding and thus with questionable impact. 


\section{Southern Common Market (Mercosur)}

Mercosur has created a relatively coherent legal framework for the protection of labor standards, including freedom of association and collective bargaining, as will be shown in this section. The organization promotes the participation of social partners in tripartite processes. In doing so, the organization references and thereby broadcasts global labor standards. This does not necessarily translate into promotion of these standards beyond the confines of the region, however.

When Mercosur was created it focused on free trade without any provision on labor (or other) rights (Ermida Uriarte 1999, 105). However, early treaties on Mercosur's institutional set-up created a Working SubGroup No. 10 on labor issues, employment and social security and the Economic and Social Advisory Forum (Olmos Giupponi 2014, 74). It is worth noting that a regional association of trade unions that predates Mercosur, the Coordinadora de Centrales Sindicales del Cono Sur founded in 1986, has a seat in both of these groups and has played a vital role in promoting the issue of workers' rights in Mercosur in the 1990s (Ermida Uriarte 1999, 117). Mercosur member states signed the Multilateral Social Security Agreement in 1997 and the Mercosur Socio-Labor Declaration in the following year (Olmos Giupponi 2014, 75). The Declaration referenced a number of human rights treaties, but importantly also the ILO Declaration on Fundamental Principles and Rights at Work which had just been adopted that same year (Mercosur 1998, 1). It contained a number of individual worker rights, but also the right to freedom of association and collective bargaining. This included, explicitly, a right to strike (Mercosur 1998, 6-7). The parties to the declaration furthermore committed to fostering social dialogue (Mercosur 1998, 7). The Declaration was non-binding, however, and Mercosur treaties generally need to be incorporated into the domestic laws of most member states (Malamud 2020; Olmos Giupponi 2014).

In terms of enforcement bodies, the Declaration created a Regional Socio-Labor Commission, though with purely promotional tasks and without any means of sanctioning member states (Mercosur 1998, 10-11). It should be noted that as the Socio-Labor Declaration was not directly linked to the founding documents of Mercosur, violations of the norm could also not be dealt with within the Mercosur dispute settlement mechanisms (Castello 2016, 79). There has been quite some debate on whether 
it might be directly applicable, and this depended on the legal systems of the member states: Only the Argentinian constitution follows the principle of monism, that is direct applicability of international norms (Olmos Giupponi 2014). In any case, the declaration contained many rights that are granted with reference to national legislation, but regardless of national differences in transposition, Castello $(2016,79)$ contends that labor tribunals in all member states have made reference to the Declaration in rulings.

The Declaration was updated in 2015 after a tripartite process and aims to reaffirm and deepen labor rights (Castello 2016). The 2015 declaration reiterates its support for the ILO Fundamental Principles and Rights at Work, but also takes up more recent international discourse on labor standards, putting the ILO "Decent Work" agenda at center stage (Mercosur 2015). This entails the inclusion of a number of standards for individual workers like maximum work hours (Castello 2016, 84), though collective rights are also slightly expanded in the new document: Signatory states commit to efforts to actively strengthen employees' (and employers') representation and collective bargaining mechanisms, the latter now also explicitly open to public sector employees (Castello 2016, 84). The revised declaration also substantiates the competencies of the Socio-Labor Commission which can now make recommendations to member states and meets twice as often as before (Mercosur 2015, 14-16).

The previous sections have shown that agreements on labor standards within Mercosur are developing. There is also a certain degree of technical cooperation through the Mercosur Labor Market Observatory established in 1998 to monitor labor market developments (Munck 2001, 18). In how far Mercosur advocates labor standards in its relations with other countries is less clear. Franca-Filho, Lixinski and Olmos Giupponi (2014, 821-822) point out that Mercosur has concluded trade agreements with various countries in the Middle East, North Africa, Latin America and South Asia without including human rights provisions. In conclusion, Mercosur can be seen as a broadcaster of ideas (Niemann et al. in this volume) regarding global labor standards such as Decent Work or the CLS at the regional level. The development of these norms was aided by the strong presence of labor actors such as trade unions in the process of regional integration. 


\section{LABOr STANDARDS FOR EvEryone? An OutLOOK}

In this chapter we compared how three International and two Regional Organizations, namely the ILO, the WTO and the World Bank, as well as ASEAN and Mercosur, approach the global governance of labor standards. We argue that two main discourses have been pursued in the global debate, a 'social' discourse and a 'neoliberal' discourse. We find that organizations whose intrinsic features allow for an institutionalized representation of worker's interests pursue variations of the social discourse, whereas those that do not stay closer to a neoliberal position. This is true both at the international and regional level. We furthermore show that the coexistence of these two conflicting discourses has led to contestation, but also exchange and cooperation, and that the ILO remains the cognitive authority in the field.

Two sets of challenges seem especially relevant for the future of global governance on labor standards. First, there is still a gap between promises and enforcement due to capacity constraints, market pressures and 'cheap ratification'. In how far this gap will be closed depends on the ability of the ILO and powerful trading partners, such as the US and the EU, to incentivize pro-labor reforms. Second, the rapid technological transformation across industries and manufacturing sites results in a wide range of changes, in terms of the nature of formal work contracts, industrial relations at the workplace and how the global production network will be organized across nations. This new wave of technology will alter the traditional understanding of actual bargaining power of low-skilled workers at firms and factories in both developed or developing countries. The coming leap forward in technology challenges the existing global labor governance regime to catch up with industry practices and market forces as well as to come up with new governance strategies in order to limit the effect of negative externalities or social disruption on the poor, low-skilled working class. In how far these developments will weaken or strengthen the relative power of the social discourse remains to be seen.

\section{REFERENCES}

Abouharb, M. Rodwan, and David Cingranelli. 2007. Human Rights and Structural Adjustment. Cambridge: Cambridge University Press.

Acharya, Amitav. 1997. "Ideas, Identity, and Institution building: From the 'ASEAN Way' to the 'Asia Pacific Way'?” The Pacific Review 10 (3): 319-346. doi:https://doi.org/10.1080/09512749708719226. 
Alston, Philip. 2004. "'Core Labour Standards' and the Transformation of the International Labour Rights Regime." European Journal of International Law 15 (3): 457-521. doi:https://doi.org/10.1093/ejil/15.3.457.

Alston, Philip. 2005. "Facing up to the Complexities of the ILO's Core Labour Standards Agenda." European Journal of International Law 16 (3): 467-480. doi:https://doi.org/10.1093/ejil/chil26.

Anner, Mark. 2012. "Corporate Social Responsibility and Freedom of Association Rights: The Precarious Quest for Legitimacy and Control in Global Supply Chains." Politics and Society 40 (4): 609-644. doi:https://doi. org/10.1177/0032329212460983.

Anner, Mark, and Teri Caraway. 2010. “International Institutions and Workers' Rights: Between Labor Standards and Market Flexibility." Studies in Comparative International Development 45 (2): 151-169. doi:https://doi. org/10.1007/s12116-010-9064-x.

ASEAN. 1993. "Resolution on the ASEAN Plan of Action for Children." Accessed September 26, 2019. http://arc-agreement.asean.org/file/doc/2015/01/ resolution-on-the-asean-plan-of-action-for-children-1.pdf.

ASEAN. 2012a. "ASEAN Guidelines on Good Industrial Relations Practices." Accessed March 06, 2020. https://www.asean.org/wpcontent/uploads/ images / 2012/publications /Guidelines\%20on\%20Good\%20Industrial\%20 Relations, \%20Nov\%202012.pdf.

ASEAN. 2012b. "Joint Communique of the Second Meeting of the ASEAN Labour Ministers Pattaya, Bangkok, 26-28 May 1977.” Accessed April 15, 2019. https://asean.org/?static_post=joint-communique-of-the-secondmeeting-of-the-asean-labour-ministers-pattaya-bangkok-26-28-may-1977.

ASEAN. 2013. "ASEAN Human Rights Declaration and the Phnom Penh Statement on the Adoption of the ASEAN Human Rights Declaration (AHRD)." Accessed March 06, 2020. https://www.asean.org/storage/ images/ASEAN_RTK_2014/6_AHRD_Booklet.pdf.

ASEAN. 2016a. "ASEAN Socio-Cultural Community Blueprint 2025." Accessed March 06, 2020. https://asean.org/storage/2016/01/ASCCBlueprint-2025.pdf.

ASEAN. 2016b. "Vientiane Declaration on Transition from Informal Employment to Formal Employment Towards Decent Work Promotion in ASEAN." Accessed March 09, 2020. https://asean.org/storage/2016/09/VientianeDeclaration-on-Employment.pdf.

ASEAN. 2017. “ASEAN Labour Ministers' (ALM) Work Programme 2016-2020 and Work Plans of the Subsidiary Bodies.” Accessed March 06, 2020. https:// asean.org/storage/2012/05/FINAL-PRINTING_27Content-ALM-WP.pdf. 
ASEAN-OSHNET. 2015. "Turning Visions into Actions: Celebrating 15 Years of Collaboration." Accessed March 06, 2020. https://asean.org/storage/2012/05/Turning-Visions-into-Actions_ASEAN-OSHNET.pdf.

Baccaro, Lucio. 2014. "Orchestration for the 'Social Partners' Only: Internal Constraints on the ILO." In International Organizations as Orchestrators, edited by Kenneth Abbott, Bernhard Zangl, Philipp Genschel, and Duncan Snidal, 262-285. Cambridge: Cambridge University Press.

Bakvis, Peter, and Molly McCoy. 2008. Core Labour Standards and International Organizations: What in-Roads Has Labour Made? Bonn: Friedrich-Ebert-Stiftung.

Barrientos, Stephanie, and Sally Smith. 2007. "Do Workers Benefit from Ethical Trade? Assessing Codes of Labour Practice in Global Production Systems." Third World Quarterly 28 (4): 713-729. doi: https://doi. org/10.1080/01436590701336580.

Bartley, Tim. 2005. "Corporate Accountability and the Privatization of Labor Standards: Struggles over Codes of Conduct in the Apparel Industry." Research in Political Sociology 14: 211-244. http://citeseerx.ist.psu.edu/viewdoc/dow nload?doi=10.1.1.218.7724\&rep=repl \&type=pdf. Accessed March 25, 2020.

Béland, Daniel, and Mitchell A. Orenstein. 2013. "International Organizations as Policy Actors: An Ideational Approach." Global Social Policy 13 (2): 125-143. doi: https://doi.org/10.1177/1468018113484608.

Berliner, Daniel, Anne Greenleaf, Milli Lake, and Jennifer Noveck. 2015. "Building Capacity, Building Rights? State Capacity and Labor Rights in Developing Countries." World Development 72 (August): 127-139. doi: https://doi. org/10.1016/j.worlddev.2015.02.018.

Bhagwati, Jagdish. 2001. "After Seattle: Free Trade and the WTO." International Affairs 77 (1): 15-30. doi: https://doi.org/10.1111/1468-2346.00175.

Blanchard, Olivier, and Justin Wolfers. 2000. "The Role of Shocks and Institutions in the Rise of European Unemployment: The Aggregate Evidence." The Economic Journal 110 (462): C1-C33. doi: https://doi. org/10.1111/1468-0297.00518.

Blanton, Robert G., Shannon L. Blanton, and Dursun Peksen. 2015. "The Impact of IMF and World Bank Programs on Labor Rights." Political Research Quarterly 68 (2): 324-336. doi: https://doi. org/10.1177/1065912915578462.

Börzel, Tanja A., and Thomas Risse. 2009. "Diffusing (Inter-) Regionalism: The EU as a Model of Regional Integration.” KFG Working Paper Series 7, Freie Universität Berlin, FB Politik- und Sozialwissenschaften, Otto-Suhr-Institut für Politikwissenschaft, Kolleg-Forschergruppe The Transformative Power of Europe. https://nbn-resolving.org/urn:nbn:de:0168-ssoar-368027. Accessed March 25, 2020. 
Botero, Juan C., Simeon Djankov, Rafael La Porta, Florencio Lopez-de-Silanes, and Andrei Shleifer. 2004. "The Regulation of Labor." The Quarterly Journal of Economics 119 (4): 1339-1382. doi: https://doi. org /10.1162/0033553042476215.

Brown, Ronald C. 2016. "ASEAN: Harmonizing Labor Standards for Global Integration." Pacific Basin Law Journal 33 (1): 27-72. doi: https://doi. org/10.2139/ssrn.3058391.

Castello, Alejandro. 2016. "Modificación De La Declaración Sociolaboral Del Mercosur (2015): Un Avance En La Construcción De La Dimensión Social Del Proceso De Integración.” IUS ET VERITAS 24 (53): 74-88. http:// revistas.pucp.edu.pe/index.php/iusetveritas/article/view/16536. Accessed March 25, 2020.

Chan, Anita. 2003. "Racing to the Bottom: International Trade Without a Social Clause." Third World Quarterly 24 (6): 1011-1128. doi: https://doi.org/1 $0.1080 / 01436590310001630044$.

Cingranelli, David L., and David L. Richards. 2014. "The Cingranelli-Richards (CIRI) Human Rights Data Project Coding Manual Version 5.20.14." Accessed March 10, 2020. http://www.humanrightsdata.com/p/datadocumentation.html.

Cox, Robert W. 1980. "Labor and Hegemony: A Reply." International Organization 34 (1): 159-176. doi: https://doi.org/10.1017/ S0020818300004021.

Croucher, Richard, and Elizabeth Cotton. 2009. Global Unions. Global Business: Global Union Federations and International Business. London: Middlesex University Press.

Davies, Mathew. 2013. "Explaining the Vientiane Action Programme: ASEAN and the Institutionalisation of Human Rights." The Pacific Review 26 (4): 385-406. doi: https://doi.org/10.1080/09512748.2013.788066.

Davies, Ronald B., and Krishna C. Vadlamannati. 2013. "A Race to the Bottom in Labor Standards? An Empirical Investigation." Journal of Development Economics 103: 1-14. doi: https://doi.org/10.1016/j.jdeveco.2013.01.003.

Dehnen, Veronika. 2013. "Transnational Alliances for Negotiating International Framework Agreements: Power Relations and Bargaining Processes Between Global Union Federations and European Works Councils." British Journal of Industrial Relations 51 (3): 577-600. doi: https://doi.org/10.1111/ bjir. 12038 .

Delgado, Natalia. 2019. "Towards Work Liberalization: The WTO Discourse on Labour Standards and Policy." International Journal of Comparative Labour Law and Industrial Relations 35 (4): 455-482. http://www.kluwerlawonline.com/abstract.php?area=Journals\&id=IJCL2019021. Accessed March 25, 2020. 
Drezner, Daniel W. 2001. "Globalization and Policy Convergence." International Studies Review 3 (1): 53-78. doi: https://doi. org/10.1111/1521-9488.00225.

Ehmke, Ellen, Michael Fichter, Bodo Zeuner, and Nils Simon, eds. 2009. Internationale Arbeitsstandards in Einer Globalisierten Welt. Wiesbaden: VS Verlag für Sozialwissenschaften.

Ermida Uriarte, Oscar. 1999. "Instituciones Y Relaciones Laborales En El Mercosur." In Las Dimensiones Sociales De La Integración Regional En América Latina, edited by Rolando Franco and Armando Di Filippo, 103-120. Santiago de Chile: CEPAL.

Fairbrother, Peter, and Nikolaus Hammer. 2005. "Global Unions: Past Efforts and Future Prospects." Relations Industrielles/Industrial Relations 60 (3): 405-431. doi:https://doi.org/10.7202/012153ar.

Farnsworth, Kevin. 2005. "International Class Conflict and Social Policy." Social Policy and Society 4 (2): 217-226. doi: https://doi.org/10.1017/ S1474746404002301.

Fink, Simon, and Daniel Rempe. 2017. "Trade Network Analyses." In Regional Integration in the Global South: External Influence on Economic Cooperation in ASEAN, MERCOSUR and SADC, edited by Sebastian Krapohl, 91-111. Cham: Springer International Publishing. doi: https://doi. org/10.1007/978-3-319-38895-3_4.

Ford, Michele, and Michael Gillan. 2015. "The Global Union Federations in International Industrial Relations: A Critical Review." Journal of Industrial Relations $57 \quad(3)$ : 456-475. doi: https://doi. org/10.1177/0022185615574271.

Franca-Filho, Marcilio T., Lucas Lixinski, and Belén O. Giupponi. 2014. "Protection of Fundamental Rights in Latin American FTAs and MERCOSUR: An Exploratory Agenda." European Law Journal20 (6): 811-823. doi:https:// doi.org/10.1111/eulj.12107.

Fryer, John L. 2003. "The World Bank and Public Sector Unions: In Search of a Policy.” Discussion Paper. Accessed March 06, 2020. wwwl.worldbank.org/ publicsector/civilservice/acrext/feb2004attl.doc.

Gwartney, James, Robert Lawson, and Joshua Hall. 2012. Economic Freedom of the World, 2012 Report. Fraser Institute: Vancouver, BC.

Hagen, Katherine A. 2003. Policy Dialogue Between the International Labour Organization and the International Financial Institutions: The Search for Convergence. Geneva: Friedrich-Ebert-Stiftung.

Hämäläinen, Päivi, Jukka Takala, and Tan Boon Kiat. 2017. "Global Estimates of Occupational Accidents and Work-Related Illnesses 2017." Accessed March 06, 2020. http://www.icohweb.org/site/images/news/pdf/Report $\% 20$ Global\%20Estimates\%20of $\% 20$ Occupational\%20Accidents $\% 20$ and $\% 20$ Workrelated\%20Illnesses\%202017\%20revl.pdf. 
Hassel, Anke. 2008. "The Evolution of a Global Labor Governance Regime." Governance 21 (2): 231-25l. doi: https://doi.org/10.111l/j.1468-049l $.2008 .00397 . x$.

Hassel, Anke, Henni Hensen, and Anne Sander. 2008. "Global Labor." In The International Studies Compendium Project, edited by Robert A. Denemark. Oxford: Blackwell.

Haworth, Nigel, Stephen Hughes, and Rorden Wilkinson. 2005. "The International Labour Standards Regime: A Case Study in Global Regulation." Environment and Planning A 37 (11): 1939-1953. doi:https://doi. org/10.1068/a37195.

Hendrickx, Frank, Axel Marx, and Glenn Rayp. 2016. "The Architecture of Global Labour Governance." International Labour Review 155 (3): 339-355. doi: https://doi.org/10.1111/j.1564-913X.2015.00039.x

Hilgert, Jeff. 2009. "Mapping the Boundaries of Human Rights at Work: Questioning How the ILO Defines Labor Rights and Social Justice." Labor Studies Journal 34 (1): 21-38. doi:https://doi.org/10.117 7/0160449X08328944.

Hurd, Ian. 2003. "Labour Standards through International Organisations: The Global Compact in Comparative Perspective." The Journal of Corporate Citizenship 11: 99-111. https://www.jstor.org/stable/jcorpciti.11.99. Accessed April 27, 2020.

ILO. 1944. "Declaration of Philadelphia, Authentic Text." Accessed March 10, 2020. https://www.ilo.org/wcmsp5/groups/public/\%2D\%2Ddgreports $/ \% 2 \mathrm{D} \% 2 \mathrm{D}$-dcomm/documents/normativeinstrument/ wcms_698995.pdf.

ILO 1998. "ILO Declaration on Fundamental Principles and Rights at Work and its Follow-up". Accessed May 6, 2020. https://www.ilo.org/wcmsp5/ groups/public/\%2D $\% 2 \mathrm{D}$-ed_norm/\%2D $\% 2 \mathrm{D}$-declaration/documents/normativeinstrument/wcms_716594.pdf.

ILO. 2002. "Information Leaflet 2002." Accessed September 26, 2019. https:// www.ilo.org/wcmsp5/groups/public/@dgreports/@dcomm/@webdev/documents/publication/wcms_082361.pdf.

ILO. 2019a. "Organizing Informal Economy Workers into Trade Unions: A Trade Union Guide.” Accessed March 10, 2020. https://www.ilo.org/ wcmsp $5 /$ groups/public/\%2D\%2D-ed_dialogue/\%2D\%2D-actrav/documents/publication/wcms_711040.pdf.

ILO. 2019b. Rules of the Game. An Introduction to the Standards-Related Work of the International Labour Organization. Geneva: ILO. Accessed March 09, 2020. https://www.ilo.org/wcmsp5/groups/public/\%2D\%2D-ed_ norm/\%2D\%2D-normes/documents/publication/wcms_672549.pdf.

Kaufman, Bruce E. 2004. The Global Evolution of Industrial Relations: Events, Ideas and the IIRA. Geneva: International Labour Office. 
Kolben, Kevin. 2011. "Transnational Labor Regulation and the Limits of Governance." Theoretical Inquiries in Law 12 (2): 403-437. https://heinonline.org/HOL/P?h=hein.journals / thinla 12\&i=419. Accessed March 25, 2020. Langille, Brian A. 2005. "Core Labour Rights - the True Story (Reply to Alston)." European Journal of International Law 16 (3): 409-437. doi:https://doi. org/10.1093/ejil/chil24.

Mah, Jai S. 1998. "ASEAN, Labour Standards and International Trade.” AsiaPacific Review 14 (3): 292-302. https://www.jstor.org/stable/25773492. Accessed March 25, 2020.

Malamud, Andrés. 2020. "Mercosur and the European Union: Comparative Regionalism and Interregionalism." In Oxford Research Encyclopedia of Politics, edited by Andrés Malamud: Oxford: Oxford University Press.

Martin, Nathan D., and David Brady. 2007. "Workers of the Less Developed World Unite? A Multilevel Analysis of Unionization in Less Developed Countries." American Sociological Review 72 (4): 562-584. doi:https://doi. org/10.1177/000312240707200404.

Maupain, Francis. 2005. "Revitalization Not Retreat: The Real Potential of the 1998 ILO Declaration for the Universal Protection of Workers' Rights." European Journal of International Law 16 (3): 439-465. doi:https://doi. org/10.1093/ejil/chil25.

McCallum, Jamie K. 2013. Global Unions, Local Power: The New Spirit of Transnational Labor Organizing. Ithaca: Cornell University Press.

Mercosur. 1998. "Declaración Sociolaboral Del Mercosur.” Accessed March 03, 2020. http://sice.oas.org/labor/MERCOSUR_Sociolab.pdf.

Mercosur. 2015. "Declaración Sociolaboral Del MERCOSUR Del 2015." Accessed March 03, 2020. https://www.mercosur.int/documento/ declaracion-sociolaboral-del-mercosur-del-2015/.

Morada, Noel M. 2008. "ASEAN at 40: Prospects for Community Building in Southeast Asia." Asia-Pacific Review 15 (1): 36-55. doi:https://doi. org/10.1080/13439000802134043.

Mosley, Layna. 2010. Labor Rights and Multinational Production. Cambridge: Cambridge University Press.

Munck, Ronaldo. 2001. "Globalization, Regionalism and Labour: The Case of MERCOSUR." Labour, Capital and Society / Travail, capital et société 34 (1): 8-25. www.jstor.org/stable/44706395. Accessed March 25, 2020.

Murillo, María V. 2005. "Partisanship Amidst Convergence: The Politics of Labor Reform in Latin America." Comparative Politics 37 (4): 441-458. doi:https:// doi.org/10.2307/20072903.

Murphy, Hannah. 2014. "The World Bank and Core Labour Standards: Between Flexibility and Regulation." Review of International Political Economy 21 (2): 399-431. doi:https://doi.org/10.1080/09692290.2013.779591. 
Nickell, Stephen. 1997. "Unemployment and Labor Market Rigidities: Europe Versus North America." Journal of Economic Perspectives 11 (3): 55-74. doi:https://doi.org/10.1257/jep.11.3.55.

O'Brien, Robert. 2008. "No Safe Havens: Labour, Regional Integration and Globalisation." In Regionalisation and Global Governance: The Taming of Globalisation? edited by Andrew F. Cooper, Christopher W. Hughes, and Philippe De Lombaerde, 123-148. London and New York: Routledge.

OECD. 2000. "International Trade and Core Labour Standards: A Survey of the Recent Literature." Accessed March 10, 2020. https://www.oecd-ilibrary. org/docserver/677200103808.pdf? expires $=1583857081 \& i d=i d \& a c c n a m e=g$ uest\&checksum=F5D55CF50D417802CAB6E529B2B16B2B.

Olmos Giupponi, María B. 2014. "Free Trade and Labour and Environmental Standards in MERCOSUR." Colombia Internacional 81: 67-97. doi:https:// doi.org/10.7440/colombiaint81.2014.03.

Orbie, Jan, and Olufemi Babarinde. 2008. "The Social Dimension of Globalization and EU Development Policy: Promoting Core Labour Standards and Corporate Social Responsibility." Journal of European Integration 30 (3): 459-477. doi:https://doi.org/10.1080/07036330802142178.

O'Rourke, Dara. 2003. "Outsourcing Regulation: Analyzing Nongovernmental Systems of Labor Standards and Monitoring." Policy Studies Journal 31 (1): 1-29. doi:https://doi.org/10.1111/1541-0072.00001.

Portes, Alejandro. 1994. "By-Passing the Rules: The Dialectics of Labour Standards and Informalization in Less-Developed Countries." In International Labour Standards and Economic Interdependence, edited by Werner Sengenberger and Duncan C. Campbell, 159-176. Geneva: International Institute for Labour Studies.

Potrafke, Niklas. 2013. "Globalization and Labor Market Institutions: International Empirical Evidence." Journal of Comparative Economics 4l (3): 829-842. doi:https://doi.org/10.1016/j.jce.2013.02.002.

Prügl, Elisabeth. 1999. The Global Construction of Gender: Home-Based Work in the Political Economy of the 20th Century. New York: Columbia University Press.

Ruggie, John Gerard. 2002. "The Theory and Practice of Learning Networks: Corporate Social Responsibility and the Global Compact." The Journal of Corporate Citizenship 5: 27-36. https://www.jstor.org/stable/jcorpciti.5.27. Accessed April 27, 2020.

Sale, Jonathan. 2020. "Harmonisation of Labour Laws: An Arduous Journey for ASEAN." Labour \& Industry: a journal of the social and economic relations of work 30 (1): 34-65. doi:https://doi.org/10.1080/10301763.2020.1723392.

Santos, Alvaro. 2010. "Three Transnational Discourses of Labor Law in Domestic Reform." University of Pennsylvania Journal of International Law (1): 123-202. https://heinonline.org/HOL/P?h=hein.journals/upjiel32\&i=125. Accessed March 25, 2020. 
Senghaas-Knobloch, Eva. 2019. Arbeit ist keine Ware: 100 Jahre Internationale Arbeitsorganisation. Wiesbaden: Springer Fachmedien Wiesbaden.

Sethi, S. Prakash, and Donald H. Schepers. 2014. "United Nations Global Compact: The Promise-Performance Gap." Journal of Business Ethics 122 (2): 193-208. doi:https://doi.org/10.1007/s10551-013-1629-y.

Stallings, Barbara. 2010. "Globalization and Labor in Four Developing Regions: An Institutional Approach." Studies in Comparative International Development 45: 127-50. doi:https://doi.org/10.1007/s12116-010-9066-8.

Standing, Guy. 2008. “The ILO: An Agency for Globalization?” Development and Change 39 (3): 355-384. doi:https://doi.org/10.1111/j.1467-7660.2008. 00484.x.

Thomas, Huw, and Peter Turnbull. 2017. "From Horizontal to Vertical Labour Governance: The International Labour Organization (ILO) and Decent Work in Global Supply Chains." Human Relations 71 (4): 536-559. doi:https:// doi.org/10.1177/0018726717719994.

van Liemt, Gijsbert. 1989. “Minimum Labour Standards and International Trade: Would a Social Clause Work?” International Labour Review 128 (4): 433-448. https://search.proquest.com/docview/224020666 accountid=14136. Accessed March 25, 2020.

van Roozendaal, Gerda. 2002. Trade Unions and Global Governance: The Debate on a Social Clause. Employment and work relations in context series. London: Continuum.

Visser, Jelle. 2019. “Trade Unions in the Balance." ILO Working Papers. Accessed March 25, 2020. https://www.ilo.org/wcmsp5/groups/public/\%2D\%2Ded_dialogue/\%2D\%2D-actrav/documents/publication/wcms_722482.pdf.

Vosko, Leah F. 2002. "Decent Work. The Shifting Role of the ILO and the Struggle for Global Social Justice.” Global Social Policy 2 (1): 19-46. doi:https://doi.org/10.1177/1468018102002001093.

Whitworth, Sandra. 1997. Feminism and International Relations: Towards a Political Economy of Gender in Interstate and Non-Governmental Institutions: Reprinted with Alterations. Basingstoke: Macmillan.

World Bank. 2018. "ESS2: Labor and Working Conditions. Guidance Notes for Borrowers." Accessed March 06, 2020. http://documents.worldbank.org/ curated/en/149761530216793411/ESF-Guidance-Note-2-Labor-andWorking-Conditions-English.pdf.

Yeates, Nicola, and Bob Deacon. 2009. "Globalisation, Regional Integration and Social Policy." In The Global Social Policy Reader, edited by Nicola Yeates and Chris Holden, 467-482. Bristol: Policy Press. 
Open Access This chapter is licensed under the terms of the Creative Commons Attribution 4.0 International License (http://creativecommons.org/licenses/ by $/ 4.0 /)$, which permits use, sharing, adaptation, distribution and reproduction in any medium or format, as long as you give appropriate credit to the original author(s) and the source, provide a link to the Creative Commons licence and indicate if changes were made.

The images or other third party material in this chapter are included in the chapter's Creative Commons licence, unless indicated otherwise in a credit line to the material. If material is not included in the chapter's Creative Commons licence and your intended use is not permitted by statutory regulation or exceeds the permitted use, you will need to obtain permission directly from the copyright holder. 